\title{
Off-loom Weaving: An Innovative and Sustainable Approach of Handcraft Development
}

\author{
Nadeem Afraz ${ }^{1 *}$, Malik Muhammad Anees ${ }^{2}$ and Talha Nadeem ${ }^{3}$ \\ ${ }^{1}$ Institute of Art \& Design, University of Sargodha, Pakistan \\ ${ }^{2}$ Senior Elementary School Educator, Department of Education, Government of the Punjab-Pakistan \\ ${ }^{3}$ Graphic Designer, Bahawlpur-Pakistan
}

Submission: October 07, 2020; Published: November 11, 2020

*Corresponding author: Nadeem Afraz, Institute of Art \& Design, University of Sargodha, Pakistan

\begin{abstract}
Designing and development of textiles is significantly affected by many factors such as fibers composition, yarn density, fabric construction and the weave design. The on-loom weaving of geometric models, complex constructions and exceptionally large repeat patterns is very common practice today. This paper has used an off-loom technique, an innovative and sustainable approach to weave large repeat angular calligraphic patterns by using wood frame, recovered knitted polyester net and woolen thread; further make it value added development with the support of domestic handcraft installations. This technique does not need much financing and sophisticated technology. Hence, it is predicted that this approach will provide the greater opportunity of self-entrepreneurship for textile designers and craft-workers.
\end{abstract}

Keywords: Off-loom weaving; Sustainable; Innovative; Textile; Handcraft; Development

\section{Introduction and Background}

It is well understood that 'Design is all around you, everything man-made has been designed [1]. The fabric structure designing is art of the fabrics development for different end uses. The simple woven fabric construction carries two set of yarn (warp and weft threads) that are interlaced at right angle to each other and made a geometrical shape [2-4]. In complex woven constructions, there are more than one series of threads, of which one set form a body or ground and other set forms the figure, lettering or surface design. The weaving of designs that well known as geometric modeling is one of the very common practices today [5] and usually developed by using dobby loom. The weave repeats with exceptionally large patterns and complex constructions are developed with Jacquard loom [6]. The major studies emphasize that industry is struggling to balance out among the sustainable development and the manufacturing cost pressure. Developments that involving large weaves pattern are not remains cost effective through onloom weaving due to their limited commercial applications. The weaving of calligraphy letterings is complex design construction. The professional calligraphers provide hand-written calligraphic handcraft for home decoration [7]. The objective of this research work is to present an innovative but sustainable technique to weave large repeat angular Arabic calligraphy and to make it value added development with the support of domestic handcraft installations.

\section{Material and Methodology}

The knitted fabric net of $100 \%$ polyester for the body of fabric and recovered wool twin yarn to use as insertion thread are acquired from commercial source and washed separately with detergent and dried. The polyester net is well ironed to remove its wrinkle. The insertion yarn doubled and twisted to give it bulkiness and strength. A wooden frame is used to fix the polyester net accordance with required size of handcraft. The frame sides are $25 \mathrm{~mm}$ wide, $20 \mathrm{~mm}$ thick and provided with $5 \mathrm{~mm}$ slots on its back. To maintain the dimension stability of polyester net and keep its grainlines aligned, the net is fastness in frame slots firmly by fixing it with ordinary jute rope in provided slots (A) (Figure 1).

To develop angular calligraphic patterns, principle of weft rib is used. Initially, angular calligraphy patterns are developed on graph paper. The insertion threads are extended along the width to develop weave pattern on face side with the support of net structure (B). To preset the developed calligraphy pattern before its removal from the wood frame; a $1.5 \mathrm{~mm}$ thick semi-hard press sheet is prepared in accordance with the full size of polyester 
net and its one side is covered with card paper (same as color of polyester net) followed by saturating it with commercial adhesive material and pasted it over the back of net fabric and left it for couple of hours to dry. Once the developed calligraphy pattern (C) well bonded and preset with press sheet, it is removed from frame.
To maintained calligraphy pattern outline visually attractive; it is mounted with paper sheet, covered with transparent glass and framed with PVC or wood material (D). Hanging string and hooks are used for holding in display as a handcraft.

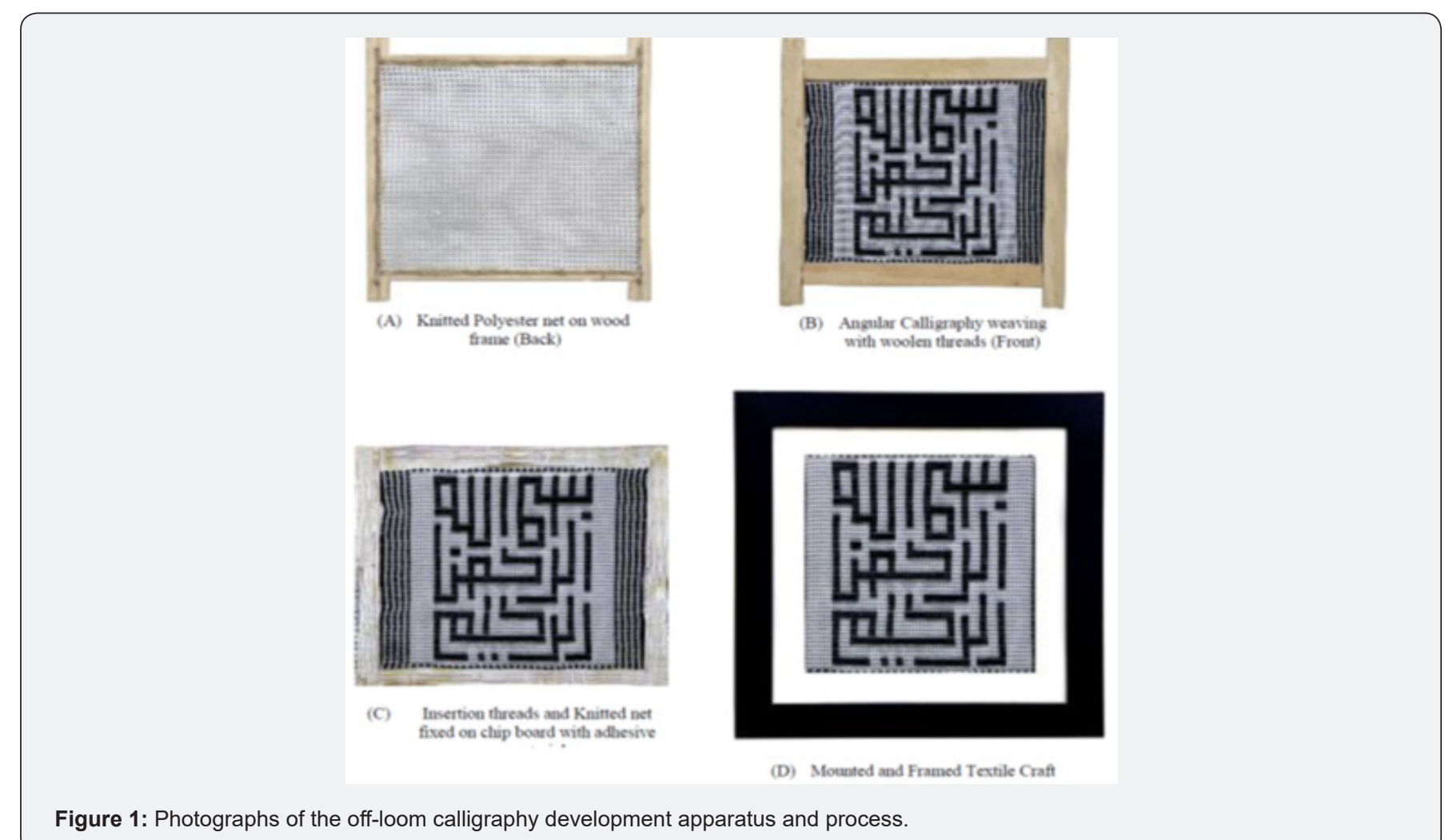

\section{Discussion}

Calligraphy is also referred to a visual class of Paleography. The Arabs defined calligraphy as 'the geometry of the line'. In Islamic states and moreover in China, Japan and India calligraphy is exclusively done by hand brush and has been greatly valued art in several centuries. In the west, it eventually evolves from initial Café painting, such as those (35000-20000 B.C.) at Lascaux, France, into the concepts that develop into the recognizable letter forms of the Alphabet [8]. In the past, the techniques used for calligraphy writing is pen, pencil, brush, ink stone, wheat stark, hand needle threading and embroidery and weaving. The cutting of thermopole metal, silver, gold, wood and Plaster-of-Paris were also used for calligraphy [7,9]. The most of techniques of calligraphy development can be assumed as sustainable. However, each handcraft development technique has its own visual, aesthetic and functional characteristics depending on the conversion process. The off-loom weaving technique is not only a sustainable but also an innovative because all material such knitted polyester net, woolen thread are used after recycling process that not only developed as value added domestic handcraft installation but also lower the overall waste.

\section{Conclusion}

Generally, textiles conversion processes are extremely energy, water and chemical-intensive regardless to the type of product. The major studies emphasize that the industry is struggling to balance out among the sustainable development and manufacturing cost pressure. The presented approach is highly energy intensive as handcrafts is cheap means of craft developments and has high demand and double worth in the major metropolitan cities and globally. The consumers of these artistic goods are belonging to elite class; thus, the craft entrepreneurs are expanding to the urban areas. However, these mass merchant exploit craft designers and the returns of their craft skills are miserable. A high degree of females' labor contribution is noticed in handcrafts development. However, they have a tendency to leave home weaving and textiles making because of partial and unpredictable markets; time consuming and tedious practice of manufacturing. Consequently, these small-scale fabrications may provide the greater opportunity to designers and craft workers to develop innovative products with material exploration. The cultural handcrafts are often turning out to be the primary means of income of an indigent society. It is predicted that this sustainable, but an innovative approach may 
encourage craft workers and textiles designers to adopt these artistic skills as their occupation for self-entrepreneurship and offers jobs to the individual and members of the society.

\section{References}

1. Hunter M (2010) What design is and why it matters. Design Council.

2. Kim S (2011) Development of a Parametric Design Method for Various Woven Fabric Structures. Journal of Engineered Fibers and Fabrics $6(4)$.

3. Mathur K, Seyam AF (2011) Color and Weave Relationship in Woven Fabrics, Advances in Modern Woven Fabrics Technology in Tech, pp. 129-151.

4. Young HD (1958) Weave on Diagonal. in Helen Daniels Young Monograph, T.C.C. Weavers, Editor. Two Cape Cod Weavers: Brewster, Massachusetts.
5. Sharma N, Kanwar P, Rekha A (2008) Traditional Handcraft and handloom of Kullu district, Himachal Pradesh. Indian Journal of Traditional Knowledge 7(1): 56-61.

6. Ciszuk M (2012) Silk-Weaving in Sweden During The $19^{\text {th }}$ Century. Textiles and Texts-An Evaluation of the Source Material, in Department of Product and Production Development. Chalmers University of Technology: Gothenburg, Sweden.

7. Shepherd M (2001) Learn Calligraphy: The Complete Book of Lettering and Design Paperback. ( $1^{\text {st }}$ edn), Watson-Guptill, UK.

8. Sons I (2016) Sarfarz Fine Arts, Entery Test Book. Sarfraz Artist Publisher, Pakistan.

9. Alashari DM (2015) Engendering Contemporary Calligraphy Through Islamic Heritage: The Spirit of Arabic Calligraphy. (Master of Fine Arts in Painting), Savannah College of Art and Design, Savannah USA.

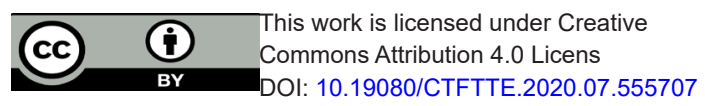

\section{Your next submission with Juniper Publishers will reach you the below assets}

- Quality Editorial service

- Swift Peer Review

- Reprints availability

- E-prints Service

- Manuscript Podcast for convenient understanding

- Global attainment for your research

- Manuscript accessibility in different formats

( Pdf, E-pub, Full Text, Audio)

- Unceasing customer service

Track the below URL for one-step submission https://juniperpublishers.com/online-submission.php 